\title{
Balloon atrial septostomy in the neonatal intensive care unit
}

\author{
E J BAKER, L D ALLAN, M J TYNAN, O D H JONES, M C JOSEPH, P B DEVERALL \\ From the Department of Paediatric Cardiology, Guy's Hospital, London
}

SUMMARY In eight infants with complete transposition of the great arteries balloon atrial septostomy was performed in the neonatal intensive care unit solely under cross sectional echocardiographic control. One infant developed necrotising enterocolitis; otherwise there were no complications. This technique eliminates the need for radiographic screening during the procedure, is quick, and causes little disturbance to the infant who does not have to be removed from the incubator.

Balloon atrial septostomy is accepted as the best initial palliative treatment in infants with complete transposition of the great arteries. The original technique ${ }^{1}$ required careful positioning of the balloon catheter within the left atrium by radiographic screening during a full investigative cardiac catheterisation. Recently, cross sectional echocardiography has been used to help position the balloon catheter during the procedure. ${ }^{23}$ The advantages given for this method were (a) the increased speed in performing the procedure, (b) the reduced risk of trauma to atrioventricular valves and other vital structures, and (c) reduced exposure to radiation. The technique also enables the operator directly to assess the adequacy of the septostomy at the end of the procedure.

Since our initial report ${ }^{2}$ we have performed 20 balloon septostomies under echocardiographic control in the cardiac catheter laboratory with no complications due to the procedure. With increasing experience we have been able to dispense with the use of radiographic screening altogether and have now performed balloon septostomies in eight infants with complete transposition of the great arteries in the neonatal intensive care unit solely under echocardiographic control.

\section{Patients and methods}

Eight consecutive patients who were considered to require balloon atrial septostomy presenting between December 1982 and October 1983 form the basis of this report (Table). Six infants, who were all less than

Requests for reprints to Dr E J Baker, Department of Paediatrics, Guy's Hospital, London SE1 9RT.

Accepted for publication 29 November 1983
36 hours old, had complete transposition with an intact ventricular septum. Two presenting at 3 days and 3 weeks of age had complete transposition with a ventricular septal defect.

The diagnosis was confirmed in each case by cross sectional echocardiography. Balloon septostomy was then performed in the neonatal unit without further investigation. The technique using cross sectional echocardiography has been described. ${ }^{2}$ In four of the infants a $5 \mathrm{~F}$ single lumen Edwards laboratories septostomy catheter was successfully introduced via the umbilical vein. In three infants the catheter would not pass through the ductus venosus and was therefore introduced percutaneously via the right femoral vein. In the infant presenting at 3 weeks old the percutaneous route was used electively.

In all cases balloon septostomy was completed without complication. One infant, already receiving an infusion of prostaglandin $E_{2}$, had a prolonged apnoeic episode as the catheter was being introduced but before balloon septostomy had been attempted and required intubation and mechanical ventilation. This was presumably a complication of the prostaglandin treatment.

In all cases echocardiography showed an adequate interatrial communication, which was confirmed at catheterisation and subsequent definitive surgery in five and at necropsy in one. Each case showed an improvement in the arterial $\mathrm{PO}_{2}$ after the procedure (Table).

There was one hospital death and one late death. The hospital death occurred 10 days after the septostomy and was due to necrotising enterocolitis. The late death occurred after an early Senning operation at 3 months of age in an infant who had developed severe subvalvular left ventricular outflow tract obstruction. 
Table Data on eight infants with transposition of the great arteries

\begin{tabular}{|c|c|c|c|c|c|}
\hline \multirow[t]{2}{*}{ Case No } & \multirow[t]{2}{*}{ Diagnosis } & \multirow{2}{*}{$\begin{array}{l}\text { Age at } \\
\text { presentation }\end{array}$} & \multicolumn{2}{|l|}{ Arterial $\mathrm{PO}_{2}(k \mathrm{~Pa})$} & \multirow[t]{2}{*}{ Outcome } \\
\hline & & & Before septostomy & After septostomy & \\
\hline $\begin{array}{l}1 \\
2 \\
3 \\
4 \\
5\end{array}$ & $\begin{array}{l}\text { TGA } \\
\text { TGA, VSD } \\
\text { TGA } \\
\text { TGA } \\
\text { TGA }\end{array}$ & $\begin{array}{l}9 \mathrm{~h} \\
3 \mathrm{~d} \\
10 \mathrm{~h} \\
7 \mathrm{~h} \\
17 \mathrm{~h}\end{array}$ & $\begin{array}{l}3 \cdot 1 \\
4 \cdot 0 \\
3 \cdot 6 \\
3 \cdot 8\end{array}$ & $\begin{array}{l}9 \cdot 2 \\
6 \cdot 2 \\
4 \cdot 7 \\
5 \cdot 3 \\
5 \cdot 1\end{array}$ & $\begin{array}{l}\text { Senning operation at } 6 \text { months } \\
\text { Awaiting corrective surgery } \\
\text { Senning operation at } 7 \text { months } \\
\text { Senning operation at } 3 \text { months (died) } \\
\text { Necrotising enterocolitis } \\
\text { (died at } 10 \text { days) }\end{array}$ \\
\hline $\begin{array}{l}6 \\
7 \\
8\end{array}$ & $\begin{array}{l}\text { TGA, VSD } \\
\text { TGA } \\
\text { TGA }\end{array}$ & $\begin{array}{l}3 \mathrm{w} \\
6 \mathrm{~h} \\
36 \mathrm{~h}\end{array}$ & $\begin{array}{l}3 \cdot 0 \\
3 \cdot 0 \\
3 \cdot 7\end{array}$ & $\begin{array}{l}6 \cdot 7 \\
8 \cdot 8 \\
5 \cdot 4\end{array}$ & $\begin{array}{l}\text { Senning operation at } 3 \text { months } \\
\text { Well (at } 1 \text { month) } \\
\text { Well (at } 1 \text { month) }\end{array}$ \\
\hline
\end{tabular}

TGA, complete transposition of the great arteries; VSD, ventricular septal defect.

\section{Discussion}

Improved intensive care facilities have led to increased survival after balloon septostomy. ${ }^{4}$ With cross sectional echocardiography the procedure can be performed in ideal conditions for the infant with the minimal delay. Indeed, in three of the cases reported here the procedure was completed within 45 minutes of the infants' admission to the unit. In four of the eight cases the infants were severely hypoxic and acidotic on admission; three required ventilation. Transferring them to a cardiac catheterisation laboratory would have entailed delay, disturbance to the infant, and removal from a controlled thermal environment.

One infant developed severe necrotising enterocolitis three days after the procedure and subsequently died despite extensive bowel resection. Two factors may have contributed to the development of this complication. Firstly, the baby was severely hypoxic and acidotic on admission to this unit at 17 hours of age and required ventilation. Secondly, determined efforts were made to perform the procedure via the umbilical vein before using the percutaneous route. Because of this experience we recommend the use of antibiotic prophylaxis when the umbilical vein is used for access. Furthermore, this route should not be persisted with if the catheter does not pass easily from the umbilical vein into the right atrium.

Full cardiac catheterisation is not required for the diagnosis or assessment of neonates with complete transposition. Complete transposition may be diagnosed reliably by cross sectional echocardiography. In our unit, since we began using this technique the diagnosis has been made correctly in every case, and there have been no false positive results. Others have had a similar experience. 56

Haemodynamic measurements taken at the time of presentation have little predictive value in this condition 48 and in our view do not justify full catheterisation in infants who are already very ill. Full invasive investigation may then be undertaken as clinically indicated. Two of our patients required early full investigation because of cyanosis and failure to thrive. In another three investigation was performed routinely at 6 months of age immediately before corrective surgery. The remaining two infants are still awaiting cardiac catheterisation.

With further experience balloon atrial septostomy in the neonatal intensive care unit, under ideal environmental conditions, may improve the survival of infants with complete transposition. Such infants can receive effective palliation without delay and without the full facilities required for cardiac catheterisation. In the future, when adequate facilities are available, the paediatric cardiologist may be able to perform balloon septostomy in the referring neonatal intensive care unit, thus further expediting urgent treatment, which is in line with current trends in the care of the critically ill neonate.

E J B is a British Heart Foundation junior research fellow.

\section{References}

1 Rashkind WJ, Miller WW. Creation of an atrial septal defect without thoracotomy. $\mathcal{F A M A} 1$ 1966; 196: 991-2.

2 Allan LD, Leanage R, Wainwright R, Joseph MC, Tynan M. Balloon septostomy under two dimensional echocardiographic control. Br Heart $\mathcal{f}$ 1982; 47: 41-3.

3 Perry LW, Ruckman RN, Galioto FM Jr, Shapiro SR, Potter BM, Scott LP. Echocardiographically assisted balloon atrial septostomy. Pediatrics 1982; 70: 403-8.

4 Leanage R, Agnetti A, Graham G, Taylor J, Macartney FJ. Factors influencing survival after balloon atrial septostomy for complete transposition of great arteries. Br Heart $\mathcal{F}$ 1981; 45: 559-72.

5 Bierman FZ, Williams RG. Prospective diagnosis of d-transposition of the great arteries in neonates by subxiphoid, two-dimensional echocardiography. Circulation 1979; 60: 1496502.

6 Bass NM, Roche AHG, Brandt PWT, Neutze JM. Echocardiography in assessment of infants with complete d-transposition of great arteries. Br Heart $\mathcal{F}$ 1978; 40: 1165-73.

7 Tynan $M$. Transposition of the great arteries; changes in the circulation after birth. Circulation 1972; 46: 809-15.

8 Tynan M. Haemodynamic effects of balloon atrial septostomy in infants with transposition of the great arteries. Br Heart $\mathcal{F}$ 1972; 34: 791-4. 